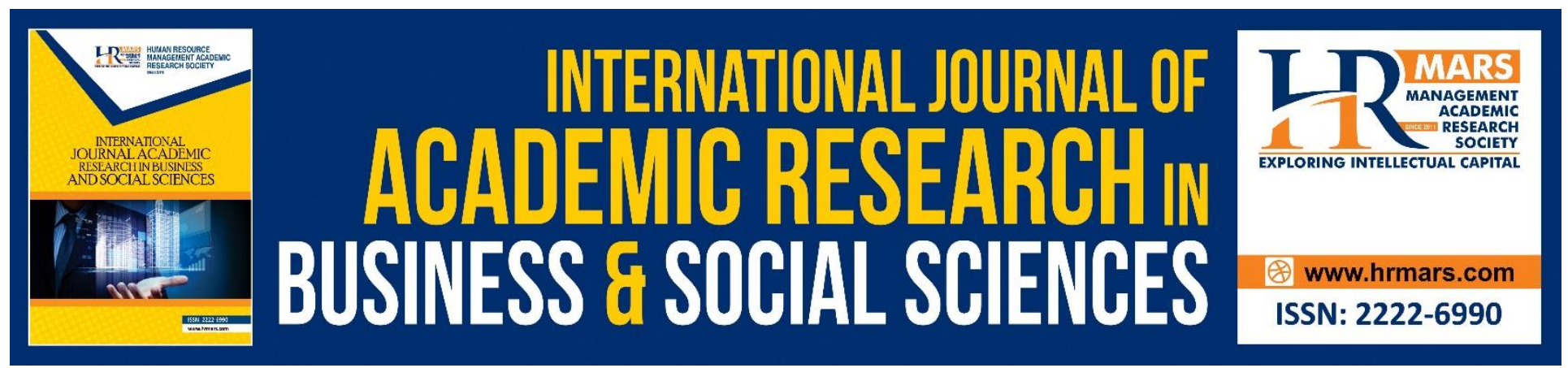

\title{
The Antecedent and Consequence of Emotional Labour among Frontline Employees in Malaysian Hotels
}

Roza Karimi, Dahlia Zawawi, Yuhanis Ab Aziz, and Steven Eric Krauss

To Link this Article: http://dx.doi.org/10.6007/IJARBSS/v10-i16/8315

DOI:10.6007/IJARBSS/v10-i16/8315

Received: 06 October 2020, Revised: 08 November 2020, Accepted: 29 November 2020

Published Online: 19 December 2020

In-Text Citation: (Karimi et al., 2020)

To Cite this Article: Karimi, R., Zawawi, D., Aziz, Y. A., \& Krauss, S. E. (2020). The Antecedent and Consequence of Emotional Labour among Frontline Employees in Malaysian Hotels. International Journal of Academic Research in Business and Social Sciences, 10(16), 317-331.

\section{Copyright: (c) 2020 The Author(s)}

Published by Human Resource Management Academic Research Society (www.hrmars.com)

This article is published under the Creative Commons Attribution (CC BY 4.0) license. Anyone may reproduce, distribute, translate and create derivative works of this article (for both commercial and non-commercial purposes), subject to full attribution to the original publication and authors. The full terms of this license may be seen at: http://creativecommons.org/licences/by/4.0/legalcode

Special Issue: Youth and Community Wellbeing: Issues, Challenges and Opportunities for Empowerment V2, 2020, Pg. 317 - 331 http://hrmars.com/index.php/pages/detail/IJARBSS JOURNAL HOMEPAGE

Full Terms \& Conditions of access and use can be found at http://hrmars.com/index.php/pages/detail/publication-ethics 


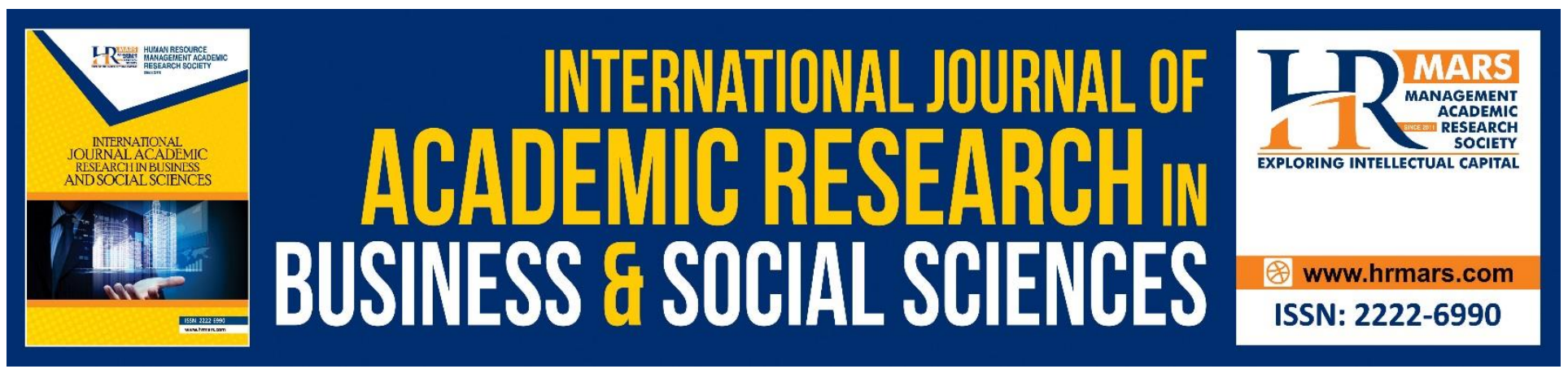

\title{
The Antecedent and Consequence of Emotional Labour among Frontline Employees in Malaysian Hotels
}

\author{
Roza Karimi ${ }^{2}$, Dahlia Zawawi ${ }^{1,3}$, Yuhanis Ab Aziz ${ }^{3}$, and Steven Eric \\ Krauss $^{1,4}$ \\ ${ }^{1}$ Institute for Social Science Studies Universiti Putra Malaysia, 43400 UPM Serdang, Selangor, \\ Malaysia, ${ }^{2}$ Graduate Student, Universiti Putra Malaysia, 43400 UPM Serdang, Selangor, Malaysia, \\ ${ }^{3}$ School of Business and Economics Universiti Putra Malaysia, 43400 UPM Serdang, Selangor, \\ Malaysia, ${ }^{4}$ Faculty of Educational Studies Universiti Putra Malaysia, 43400 UPM Serdang, Selangor, \\ Malaysia \\ Email: rosament@gmail.com,dahlia@upm.edu.my
}

\begin{abstract}
Emotional labour is sometimes viewed as the process of managing both feeling and expression to meet organizational goals, which is common in the hotel industry. While past studies have studied on the impact of emotional labour on organisational success, the antecedent and consequence of emotional labour among Malaysian hotel industry are unexplored. It is believed that when it comes to the subject of emotion, the displays frontline employees showed to customers play a significant role in the continued growth and survival of hotels. The aim of this article was to examine the model highlighting leadership as an antecedent of emotional labour (deep acting and surface acting), and burnout as an outcome of it. The data were collected through questionnaires from 300 frontline employees in the Klang Valley hotels, with data analysis being performed using structural equation modeling. The research findings reveal leadership to be the predictor of employee's emotional labour, in which it specifically improved deep acting and reduced surface acting. Also, the results suggest that deep acting can reduce burnout among employees. But there is no significant impact between surface acting and burnout. The result is discussed with reference to previous studies. Study limitation and ideas for future research direction are presented as well.
\end{abstract}

Keywords: Leadership, Emotional Labour, Deep Acting, Surface Acting, Burnout, Malaysia.

\section{Introduction}

The global tourism industry has been growing in recent years, and it has become one of the largest industries in the world. In 2019, travel and tourism contributed over 8.9 trillion to the global 
economy, which is $10.3 \%$ of global GDP. In addition, the industry also supported $4.2 \%$ employment in 2018, which is 1 in 10 of all jobs in the world. Tourism industry does not only impact positively on developed countries, it also has expended its influence as an important industry in developing countries like Asia and Africa (World Travel \& Tourism, 2019; Hassan \& Omar, 2016).

In Malaysia, tourism industry is considered as one of the main contributors to the growth of service sector in particular and national economy in general. Although the Malaysian government applied many strategies and solutions to improve tourism and the service sector to increase the country's economic growth, tourist arrival in Malaysia has dropped from 26.8M (in 2016) to 26M (in 2019). The development of the hotel sector has been comprehensively associated with the hospitality and tourism industry to sustain the government strategy and develop the economic growth of the country. According to Tourism Satellite Account, hotels are considered as the key service provider in the tourism industry for its large contribution to the total tourist expenditure with an estimation of 18\% in 2019 (Tourism Satellite Account, 2019).

Given the importance of the hotel sector in supporting the nation's tourism industry, it is vital for hotel operators to consistently maintain and improve their hotel performance by providing good service quality to their customers. According to Wang (2019), the quality of service delivered cannot be separated from the quality (or personality) of the service provider. Instead, they believe that emotion the frontline employees display to customers determine the continued growth and survival of hotels (Karatepe, 2010; Wang, 2019). Sadly, previous studies showed that hotels in Malaysia were suffering from service failures which was the cause of dissatisfaction among customers (Choo \& Tan, 2017; Ekiz, Khoo-Lattimore \& Memarzadeh, 2015). For an example, Choo and Tan (2017) reported that frontline hotel employees have lack of expertise in handling services, which in turn led to poor customer experience. In addition, they also conducted short interview with hotel human resource manager from some of hotels in Kuala Lumpur. The gist of the interviews hinted that failing of employee's acting could jeopardise the overall customer satisfaction as well as hotel performance. Therefore, hotels have to focus on employees' emotional display in an attempt to enhance customers' perceived service satisfaction.

Past researchers have studied about emotional labour's antecedents such as display rules (Adil, Kamal, \& Atta, 2013), organisational factors (Brown, Vesely, Mahatmya, \& Visconti, 2018), individual characteristics (Brotheridge \& Taylor, 2006), and emotional intelligence (Ramona, 2018). Apart from that, emotional labour's consequences were also researched like job dissatisfaction (Ahmad \& Zafar, 2018), intention to quit and turnover (Karatepe \& Aleshinloye, 2009), and service quality (Levitats, \& Vigoda-Gadot, 2017). However, there is still a lack of empirical research being done to explore other relevant antecedents and consequences of emotional labour. Consequently, most of the studies on emotional labour and workers' mental health status were focused on specific types of service sectors such as call centers, travel agencies, nursing homes, or health care workers (Delgado, Upton, Ranse, Furness, \& Foster, 2017) only. Due to these reasons, this study intends to review the antecedent and consequence of emotional labour in Malaysia hotel industries specifically leadership and burnout. 


\section{Theoretical Background and Hypothesis Affective Events Theory (AET)}

According Weiss and Cropanzano (1996) affective events theory attempts to expand an extensive framework to describe emotional experiences at work, and it is very helpful and useful in directing researchers, who are investigating on emotions at the organisation. The theory provides a theoretical concept for the study of emotions in organisation by focusing on the environment, reasons, and result of affective experiences at organisation. Based on the affective events theory, the experiment of a negative or positive organisation event (e.g., empowerment, leadership, role overload) could elicit reactions, either positive or negative that contribute to the formation of work attitude and behaviour (Mignonac \& Herrbach, 2004; Rupp \& Spencer, 2006). "Things happen to people in work settings and people often react emotionally to these events. These affective experiences have direct influences on behaviours and attitudes," (Weiss \& Cropanzano, 1996, p.11).

In fact, affective events theory presents a very effective framework in showing the role of employee's emotions in the relationship between work environment and employee manners and actions (Basch \& Fisher, 2000; Grandey, Tam, \& Brauburger, 2002; Saavedra \& Kwun, 2000). It categorised behaviour at work within two subgroups. One of them is affect-driven behaviours. This type of behaviour includes employee manner like as emotional outbursts or data processing strategies in the organisation. In contrast, judgment-driven behaviour, which is another subgroup, refers to withdrawal behaviours like leaving the job, taking decision to work efficiently, or deciding to retire. In another word, affective events theory state how emotional labour could be increased by a particular work events (e.g. leader behaviour, helping environment, promotions) and how employees' emotion could influence their evaluation and judgment about their job. Hence this theory is very useful in guiding research in regards to emotion at the organisation.

\section{The Relationship between Leadership and Emotional Labour}

Leadership is generally defined as the way of person who initiatives, enables and supports to employees and helped employee to complete tasks which employees and superiors were expected (Spillane, Hallett, \& Diamond, 2003). Leaders are identified as the main source of influence on organisation (Schein, 2017). They can direct individual employees to join efforts towards innovative work processes and outcomes (Amabile, 1996). Furthermore, they normally are responsible in designing human resource -related policies like a reward system that compensate performance. When an organisation enables intrinsic and extrinsic rewards for efforts to gain new skills and to experience with creative work approaches, employees will continuously feel reinforced to engage in creative endeavours (Jung, 2001; Mumford \& Gustafson, 1988). The positive correlation between leadership and emotional labour has relied on affect events theory and intellectual stimulation strategy.

First, the link between leadership and emotional labour is explained from the perspective of affective events theory (Weiss \& Cropanzano, 1996). This theory highlights that workplace factors make 'affective events' (hassles and uplifts) which affect the emotional reactions that, in turn, determine attitudinal and behavioural outcomes. Leaders are the key variables in the organisation environment; therefore, they might be seen as architects of affective events experienced by organisational 
employees within the affective events theory model. According to George (2000) employees shows similar emotion as their leaders. If leaders display feelings of excitement, energy, and enthusiasm, they can arouse similar feelings in their employees. In addition, leaders, who show positive emotions, are likely to engender positive emotions in employees. Thus, positive leader behaviour can be considered as an affective event in the organisation that continuously produces positive moods and deep emotions.

Deep acting means that the individual consciously modifies the feelings for the role that he or she is performing and will truly feel the emotions that he was expressing (Hochschild, Irwin \& Ptashne, 1983). The relation between leaders and deep acting is described based on intellectual stimulation strategy. Intellectual simulation means that when leaders push their followers to start thinking "out of the box," they tend to develop their process of thinking (Avolio, Sosik, \& Kahai, 2014). In other words, the leaders help stimulate their employees to think about old problems in different ways and push them to challenge their own values, beliefs and skills (Hater \& Bass, 1988). By being the role models, leaders can also help to develop followers' commitment to long-term goals by showing high expectations and confidence in them. Thus, supportive leaders will make regular small uplifts, like as positive feedback, or inspiration, which in turn help employees to overcome the daily challenges. As a result, employees feel more positive, and are more likely to engage in positive behaviours and act deeply (Weiss \& Cropanzano, 1996). Based on the above discussion, leaders could be seen as able to inculcate deep acting among employees. Therefore, the following hypothesis is postulated:

\section{H1a: There is a positive relationship between leadership and deep acting.}

The other component of emotional labour is surface acting, which happens when individual acts out certain emotions without actually feeling or making an attempt to feel them; in other words, he is regulating emotions expressed, and sees himself as "just an actor, not sincere" (Hochschild et.al., 1983). Arguments made by Gardner, Fischer, and Hunt (2009) discussed that negative incident which elicit negative feeling (such as anger) by leaders makes discrepancies between employee emotional expressions. Therefore, the employee might display higher levels of faking (negative emotion) in his/her role. To demonstrate this, Lewis (2000) result showed that leaders expressing anger towards their employees caused negative feelings like as stress, panic and fear. These discussions have been supported by literature of emotional labour. For instance, Grandey et al. (2002) found events that invoked feelings of anger (e.g. disrespect, unjust treatment from the leader or lack of leadership) increased the levels of faking behaviours (surface acting) among employees. As a result, employees, who feel negative emotional states, are more willing to perform faking action (Weiss \& Cropanzano, 1996). Therefore, it can be concluded that leadership could impact negatively on employee's emotion (surface acting). According to the above justification, the current research proposes the following hypothesis:

H1b: There is a negative relationship between leadership and surface acting. 


\section{The Relationship between Emotional Labour and Burnout}

Burnout is identified as a multidimensional construct including of emotional exhaustion, diminished personal accomplishment, and depersonalisation (Maslacht al., 1996). Many researchers confirmed the relationship between emotional labour and burnout (e.g. Brotheridge \& Grandey, 2005; Zapf, 2002; Zerbe, 2000). Result of these studies showed that deep acting reduce burnout. For example, Kruml and Geddes (2000) believed that employee experience would lessen emotional exhaustion when employees believe it to be natural. Also, Brotheridge and Grandey (2005), Brotheridge and Lee, (2003), and Grandey (2003) mentioned deep acting as a negative and direct predictor of burnout. Furthermore, the relationship between emotional labour and burnout was also examined in Iran service organisation by Ghalandari and Josh (2012). They found that deep acting can have a negative influence on burnout.

Apart from that, relationship between emotional labour and burnout can be explained by affective events theory as well. The theory provides supporting evidence for the proposition that the employees' judgment is affected by work attitude and their feelings (Fisher, 2011). Fisher also found out that affective commitment to the organisation could be a strong predictor of quitting the job. If employees deeply understand the organisation's rule and regulate emotion, they feel more positive emotion. This positive feeling results in less stress and emotional exhaustion which reduce job burnout. Based on affective events theory and previous studies (e.g. Brotheridge \& Lee, 2003; Ghalandari \& Ghale Josh, 2012; Zapf, 2002), it can hypothesised that:

\section{H2a: There is a negative relationship between deep acting and burnout.}

On the other hand, previous researchers believed that surface acting have positive impact on dimensions of burnout. Brotheridge and Grandey (2005) found that there is a positive relationship between surface acting and emotional exhaustion. Additionally, Naring, Briet, and Brouwers (2006) obtained a similar result among teachers. They found that surface acting could positively impact emotional exhaustion. Zapf and Holz (2006) focused on relationship between surface acting and other dimensions of burnout like as depersonalisation. They also discovered positive relationship between surface acting and depersonalisation.

Furthermore, affective events theory asserted that judgment driven behaviours include withdrawal such as intention to leave. Based on this theory, judgment driven behaviour requires and individual to thoughtfully consider valuation of his or her job. Therefore, the influence of affective states at work on employees' behaviour can be proposed by their emotions and the emotions are affected by work environment. According to Bono and Vey (2005) study, the effort that goes into faking an emotional expression should result in high level of emotional exhaustion that further can contribute to turnover intention. For instance, an organisation that displays rules requiring an employee to smile to customers. If employees do not have natural inclination to smile, there will be a conflict between their feelings and reality. Therefore, they have to display fake emotions. Faking emotion (surface acting) will make employees feel emotionally exhausted and increase their intention to quit. Based on the above literature (e.g. Briet \& Brouwers, 2006; Zapf \& Holz, 2006) and affective events theory, the hypothesis below is proposed: 
INTERNATIONAL JOURNAL OF ACADEMIC RESEARCH IN BUSINESS AND SOCIAL SCIENCES

Vol. 10, No. 16, Youth and Community Wellbeing: Issues, Challenges and Opportunities for Empowerment V2. 2020, E-ISSN: 2222-6990 @ 2020 HRMARS

H2b: There is positive relationship between surface acting and burnout.

Figure 1 demonstrates the proposed framework of antecedents and consequences of emotional labour in Malaysia hotel industries.

Figure 1: The proposed hypothesised framework

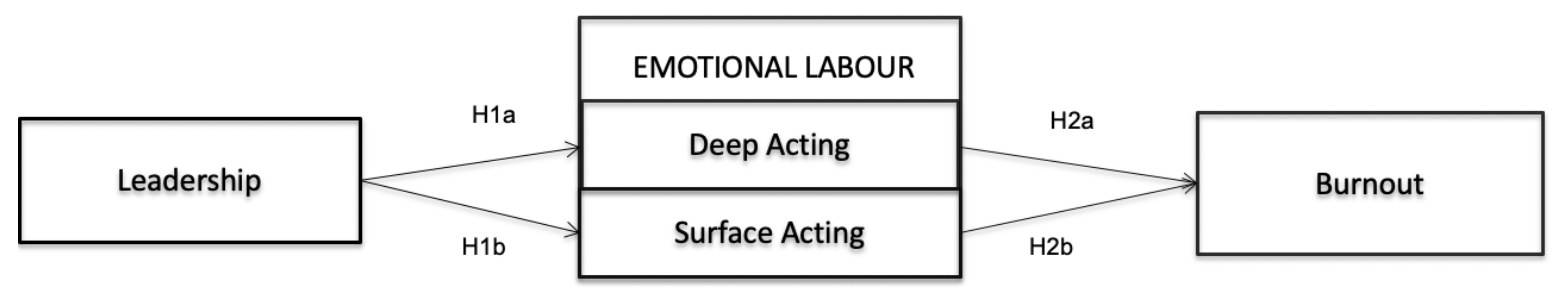

\section{Methodology}

To test the relationship of study, the quantitative method with hypotheses approach was adopted by using the survey questionnaire. The following components is discussed in this section: measurement, data collection, sampling and data analysis.

\section{Measures}

For this study, the scale measurements were adopted from prior research studies to guarantee the high validity of the questionnaire. In order to measure emotional labour, ten questions were asked altogether. The scale by Brotheridge and Lee (2003) listed six and four items to measure deep acting and surface acting respectively. Leadership's items adopted Bass and Avolio's (2004) Multifactor Leadership Questionnaire. The questionnaire was designed to measure leadership through two dimensions, transactional and transformational, comprising of 22 items. In addition, Maslach and Jackson's (1986) measurement was used for burnout. A seven-point rating (1=strongly disagree to $7=$ strongly agree) was used in this study.

\section{Data Collection and Participants}

In total, the study questionnaire comprised of four main sections. Section A to C of the study were regarding the constructs included in the conceptual framework, which were leadership, emotional labour (deep acting and surface acting) and burnout, while section D was on the respondents' demographics profile with 7 questions: gender, age, marital status, education, tenure in current organisation, occupation and race. This section applied nominal and ordinal scale, in which respondents could answer by ticking the options provided.

The population of this research was composed of frontline employees working in Malaysian hotel industry, which have been operating for at least one year. For this research, 300 front line employees were selected based on non-probability sampling technique. Non-probability sampling is a sampling technique where the odds of any member being selected for a sample cannot be calculated. Back in 2014, Rowley indicated the difficulty in obtaining a full list of front line employees of hotel industry 
in Malaysia, and to the researcher's knowledge, the data was still found to be unavailable at the time this research was conducted. The questionnaires were sent to the respondents via the human resource managers of each hotels. The rationale for using this sampling method was due to the respondents being easily accessible, their availability, as well as it being less time consuming and inexpensive to gather the research information.

\section{Data Analysis}

Structural equation modelling was used to analyse the data. The following section covers the demographic characteristic of frontline employees, reliability and validity, and structural model analysis and results.

\section{Demographic Results}

This section presents a background of the samples studied in this research. The employee's data was obtained from the two to five star hotels around the Klang Valley. As mentioned, a total of 300 completed questionnaires were received for data analysis. Looking at Table 1, the highest respondents were the male employees with a total of $57 \%$ while $43 \%$ of the frontline employees were female. One hundred and thirty-six of the frontline employees were between 21 and 30 years old (45\%) while 112 of them aged between 31 and 40 years (37\%). About 215 of the frontline employees (72\%) were single while 85 of the respondents (28\%) were married. In addition, 165 of the respondents (55\%) had completed high school, 93 of the respondents (31\%) had completed diploma and 42 of the respondents (14\%) had completed degree. Lastly, 104 of the frontline employees (35\%) has an experience less than 1 year, 24\% of them worked for 1 to 3 years, 60 of them (20\%) had been with the company for 4 to 6 years, and 63 of the respondents (21\%) had tenure of 7 to 10 years. 
INTERNATIONAL JOURNAL OF ACADEMIC RESEARCH IN BUSINESS AND SOCIAL SCIENCES

Vol. 10, No. 16, Youth and Community Wellbeing: Issues, Challenges and Opportunities for Empowerment V2. 2020, E-ISSN: 2222-6990 @ 2020 HRMARS

Table 1: Demographic Results

\begin{tabular}{|l|l|l|l|}
\hline Demographic Characteristics & & $\begin{array}{l}\text { Number of } \\
\text { Respondents (n=00) }\end{array}$ & $\begin{array}{l}\text { Percentage } \\
\mathbf{( 1 0 0 \% )}\end{array}$ \\
\hline Gender & Male & 171 & 57.0 \\
& Female & 129 & 43.0 \\
\hline Age of Respondent & $<20$ years & 44 & 15.0 \\
& $21-30$ & 136 & 45.0 \\
& $31-40$ & 112 & 37.0 \\
& $41-50$ & 8 & 3.0 \\
\hline Marital Status & Single & 215 & 72.0 \\
& Married & 85 & 28.0 \\
\hline Race & Malay & 147 & 49.0 \\
& Chinese & 95 & 32.0 \\
& Indian & 50 & 17.0 \\
& Others & 8 & 2.0 \\
\hline Educational Level & High school & 165 & 55.0 \\
& Diploma & 93 & 31.0 \\
& Bachelor's degree & 42 & 14.0 \\
\hline Tenure & <1 year & 104 & 35.0 \\
& 1-3 years & 73 & 24.0 \\
& 4-6 years & 60 & 20.0 \\
& 7-10 years & 63 & 21.0 \\
\hline
\end{tabular}

\section{Validity Analysis for Full Measurement Model}

The total of 300 observed in the sample was used for completing reliability and validity analysis. Reliability is "a measure of the degree to which a set of indicators of a latent construct is internally consistent based on how highly interrelated the indicators are with each other" (Hair, Black, Babin, Anderson, \& Tatham, 2010). According to Hair et al. (2010) the rule for data to be reliable is approximately 0.7 or even higher. In fact, the values between 0.6 and 0.7 may be accepted as reliable if other indicators of a model's construct validity are good. Construct Validity examines the relationship strength between items that represent a single latent construct. It could be tested using average variance extracted. Once average variance extracted is higher than 0.5 it showed high convergent validity (Fornell \& Larcker, 1981). Table 2 displays the outcomes for reliability and average variance extracted. Base on the result all the constructs are located in the range between 0.799 and 0.897, greater than the guideline of 0.7 (Hair et al., 2010). In other words, they are reliable. Overall, all the constructs of average variance extracted exceed the threshold value of 0.50 (Hair et al., 2010). 
INTERNATIONAL JOURNAL OF ACADEMIC RESEARCH IN BUSINESS AND SOCIAL SCIENCES

Vol. 10, No. 16, Youth and Community Wellbeing: Issues, Challenges and Opportunities for Empowerment V2. 2020, E-ISSN: 2222-6990 @ 2020 HRMARS

Table 2: Consideration Reliability and Validity for Full Model

\begin{tabular}{|l|c|c|c|}
\hline Factors/Items & $\begin{array}{c}\text { CR } \\
\text { (> 0.7) }\end{array}$ & $\begin{array}{c}\text { AVE } \\
\text { (> 0.5 ) }\end{array}$ & MSV \\
\hline Leadership -Transform & 0.94 & 0.846 & 0.353 \\
Leadership - Transact & 0.883 & 0.655 & 0.35 \\
Deep Acting & 0.91 & 0.76 & 0.26 \\
Surface Acting & 0.799 & 0.501 & 0.262 \\
Burnout - Personal Accomplishment & 0.816 & 0.6 & 0.2 \\
Burnout - Depersonalisation & 0.87 & 0.647 & 0.24 \\
Burnout - Emotional Exhaustion & 0.85 & 0.637 & 0.23 \\
\hline
\end{tabular}

\section{Structural Model Analysis and Results}

After removing the lower outer loading, Figure 2 shows the structural model for emotional labour and its antecedent and consequence. In the structural model all related construct were assigned exogenous and endogenous path to develop the proposed model. In this case, the exogenous included leadership and emotional labour, while endogenous included burnout. Next, the model was tested where factor loading is more than 0.5 and met model fit indices. The result for structural model revealed acceptable model fit without any deletion of items. The result indices in the structural model met the model fit requirement. Table 3 presents the model fit result. The result showed GFI, $\mathrm{CFI}$ and IFI are greater than $0.9(0.960)$, and RMSEA is 0.07 which is less and equal 0.08 . Therefore, no modification was made.

Table 4: Fit Indices for Model Fit Structural Model

\begin{tabular}{|lccc|}
\hline Fit Indices & Acceptance Level & Index Value & Status \\
\hline RMSEA & $<0.08$ & 0.07 & Achieved \\
GFI & $>0.90$ & 0.96 & Achieved \\
CFI & $>0.90$ & 0.96 & Achieved \\
IF & $>0.90$ & 0.96 & Achieved \\
$\chi 2 /$ df & $<5.0$ & 1.83 & Achieved \\
\hline
\end{tabular}




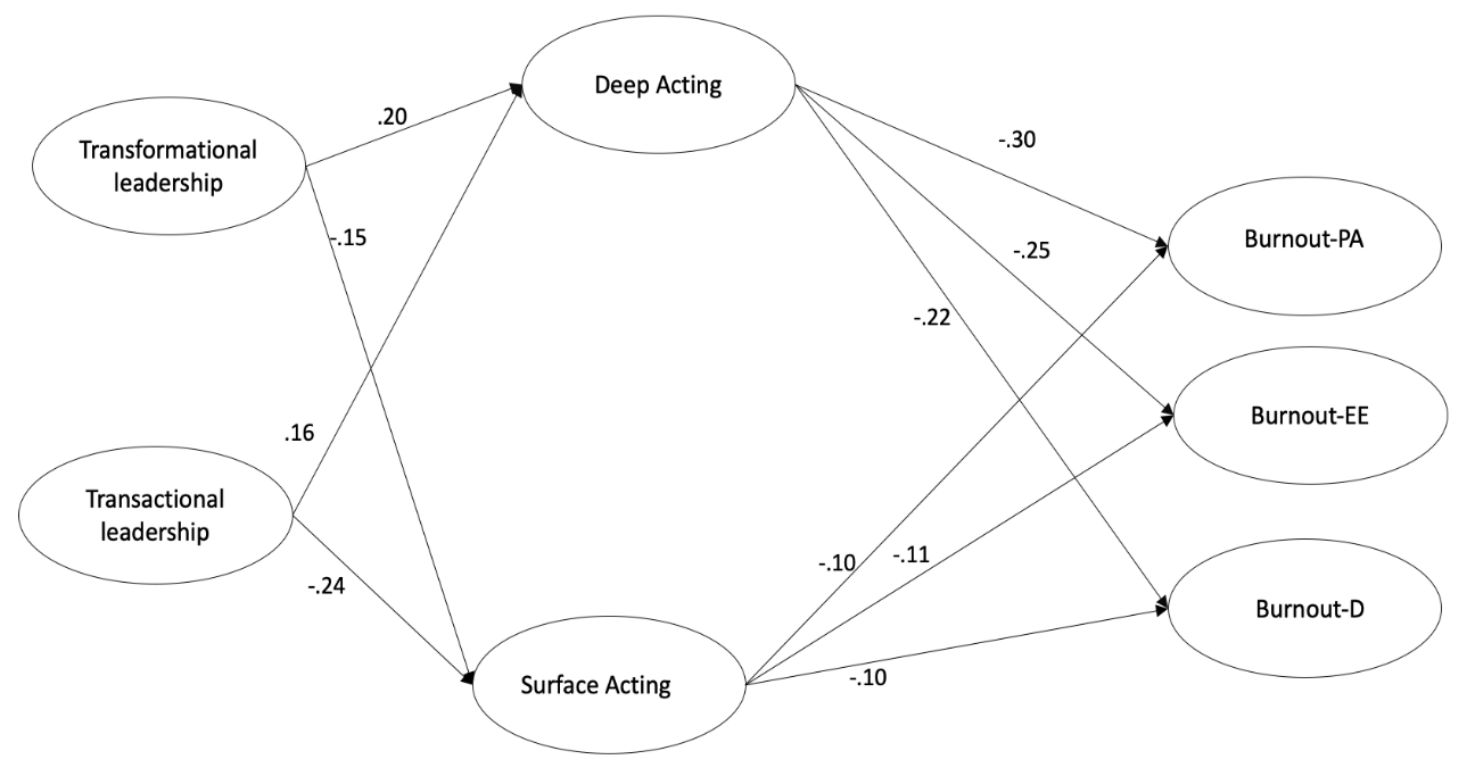

Figure 2: Structural Model

\section{Assessment of Hypothesis}

This section presents the hypothesis testing for the study. A conceptual framework in Figure 1 displayed the possible relationships between the leadership to emotional labour with the former categorised as the antecedent; and emotional labour to burnout with the later categorised as the outcome. Based on the framework, four hypotheses were formulated and tested. The results provided evidence to support the hypotheses and verified the propositions that leadership is related to surface acting and deep acting. However, the results stated that burnout was influenced by deep acting only and not surface acting (Refer Table 5).

Table 5: Result of Hypotheses Testing

\begin{tabular}{|l|l|l|l|}
\hline Hypotheses & \multicolumn{2}{l|}{ Findings } & \\
\hline H1a: There is a positive relationship between Leadership & $\beta=0.20$ & $p<0.005$ & Supported \\
and Deep Acting & $\beta=0.16$ & & \\
\hline H1b: There is a negative relationship between Leadership & $\beta=-0.15$ & $p<0.005$ & Supported \\
and Surface Acting & $\beta=-0.24$ & & \\
\hline H2a: There is a negative relationship between Deep & $\beta=-0.30$ & $p<0.005$ & Supported \\
Acting and Burnout & $\beta=-0.25$ & & \\
& $\beta=-0.22$ & & \\
\hline 2b: There is a positive relationship between Surface & $\beta=-0.10$ & $p>0.005$ & Not \\
Acting and Burnout. & $\beta=-0.11$ & & Supported \\
& $\beta=-0.10$ & & \\
\hline
\end{tabular}


Hypothesis 1a proposed a significant effect of leadership on deep acting. The results demonstrate that each of leadership transformation and transactional displays positive and significant association with deep acting $(\beta=0.20, p<0.005)$ and $(\beta=0.16, p<0.005)$. Hypothesis $1 \mathrm{~b}$ proposed a negative impact of leadership on surface acting. A negative and significant association was found between leadership transformation and transactional on surface acting $(\beta=-0.15, p<0.005)$ and $(\beta=-0.24, p<0.005)$, therefore $\mathrm{H} 1 \mathrm{a}$ is supported as well. Hypothesis $2 \mathrm{a}$ also proves that deep active reducing burnout among frontline employees. Only $\mathrm{H} 2 \mathrm{~b}$ is rejected with $(\mathrm{p}>0.005)$, which means there is no significant correlation among surface acting and burnout.

\section{Conclusion and Recommendations}

The role and importance of emotional labour in the hotel industry has been elucidated through the findings of this study. The study was initially conducted to determine if positive leadership influence emotional labour among frontline employees in Malaysia hotel industry and if emotional labour consequently affects burnout. However only three of the proposed hypotheses were accepted. Significant relationship found between leadership and emotional labour is consistent with the other researches (e.g. Walsh, Martin Ginis, Arnold \& Connelly, 2015; Liang, Tang, Wang, Lin, \& Yu, 2016; Grandey et al., 2002; Weiss \& Cropanzano, 1996). Moreover, the findings also disclosed that emotional labour except surface acting has positive impact on burnout which is consistent to some past literature such as Celiker, Ustunel, and Guzeller (2019); Yilmaz, Altinkurt, Guner and Sen (2015); Akin, Aydın, Erdogan, and Demirkasımoglu (2014); Fisher (2011); and Brotheridge and Lee (2003). The worthwhile contribution to theory offers the academician and decision makers a knowledge and awareness regarding the importance of emotional labour among employee in improving services towards customers. Apart from that, the practical implications of the study suggests that hotel managers can employ this research and knowledge to achieve better results of emotional labour by acting as role models, giving followers real opportunities to improve their skills and abilities, showing the trust and confidence in employees; giving followers positive feedback when they perform tasks well, monitoring follower performance and tracks errors during the planning process, and taking corrections whenever one unexpected thing happened.

The researcher faced some limitations during the implementation of this research. The first limitation was the quantitative nature of the study. In this kind of research, the respondents were only able to answer based on the questions. Qualitative research is however, designed to determine experiences of frontline employees who directly deal with customers and have face-to-face communication. It is especially effective in comprehensively revealing the cases which we are aware of but do not have deep and detailed knowledge about (Liamputtong, 2013). It is suggested that the future study includes the qualitative method to complement the findings. The second limitation of this study was the sample that was confined to the Klang Valley area. Due to the frontline employees to always have a very busy schedule, it was difficult to get their time and cooperation. Therefore, replicating the study in other areas and other tourism organisations (e.g. airline, restaurant, travel agency) in Malaysia is recommended. Last but not least, as both employees and customers are equally important to assess service performances of the hotel, it is suggested that any future study could consider this aspect and include both types of respondents in the effort to encapsulate the bigger picture of the relationship between the variables. 


\section{References}

Adil, A., Kamal, A., \& Atta, M. (2013). Mediating role of emotions at work in relation to display rule demands, emotional labor, and job satisfaction. Journal of Behavioural Sciences, 23(3), 35-52.

Ahmad, I., \& Zafar, M. A. (2018). Impact of psychological contract fulfilment on organisational citizenship behavior. International Journal of Contemporary Hospitality Management, 30(2), 1001-1015.

Akin, U., Aydın, I., Erdogan, C., \& Demirkasımoglu, N. (2014). Emotional labor and burnout among Turkish primary school teachers. The Australian Educational Researcher, 41(2), 155-169.

Avolio, B. J., Sosik, J. J., Kahai, S. S., \& Baker, B. (2014). E-leadership: Re-examining transformations in leadership source and transmission. The Leadership Quarterly, 25(1), 105-131.

Basch, J., \& Fisher, C. D. (2000). Affective job events-emotions matrix: A classification of job related events and emotions experienced in the workplace. In Ashkanasy, Neal M., Charmine EJ Härtel, and Wilfred J. Zerbe (Eds.), Emotions in the workplace: Research, theory, and practice (pp. 36-48), London: Quorum Books.

Bass, B. M., \& Avolio, B. J. (2004). Multifactor Leadership Questionnaire: MLQ; manual and sampler set. Mind Garden.

Brotheridge, C. M., \& Lee, R. T. (2003). Development and validation of the emotional labour scale. Journal of Occupational and Organizational Psychology, 76(3), 365-379.

Brotheridge, C. M., \& Grandey, A. A. (2005). Emotional labor and burnout: Comparing two perspectives of "people work". Journal of Vocational Behavior, 60(1), 17-39.

Brotheridge, C. M., \& Taylor, I. (2006). Cultural differences in emotional labor in flight attendants. Research on Emotion in Organizations, 2, 167-191.

Brown, E. L., Vesely, C. K., Mahatmya, D., \& Visconti, K. J. (2018). Emotions matter: the moderating role of emotional labour on preschool teacher and children interactions. Early Child Development and Care, 188(12), 1773-1787.

Bono, J. E., \& Vey, M. A. (2005). Toward understanding emotional management at work: A quantitative review of emotional labor research. Emotions in Organisational Behavior, 213233.

Celiker, N., Ustunel, M. F., \& Guzeller, C. O. (2019). The relationship between emotional labour and burnout: a meta-analysis. Anatolia, 30(3), 328-345.

Choo, P. W., \& Tan, C. L. (2017). Factors Influencing Poor Experience Quality in 2-To-5-Star Hotels: A Content Analysis of Guest Reviews on Trip Advisor. Global Business and Management Research, 9(4s), 409-425.

Delgado, C., Upton, D., Ranse, K., Furness, T., \& Foster, K. (2017). Nurses' resilience and the emotional labour of nursing work: An integrative review of empirical literature. International Journal of Nursing Studies, 70, 71-88.

Ekiz, E., Khoo-Lattimore, C., \& Memarzadeh, F. (2012). Air the anger: investigating online complaints on luxury hotels. Journal of Hospitality and Tourism Technology, 3(2), 96-106.

Fisher, M. H. (2011). Factors influencing stress, burnout, and retention of secondary teachers. Current Issues in Education, 14(1), 3-37.

Gardner, W. L., Fischer, D., \& Hunt, J. G. J. (2009). Emotional labor and leadership: A threat to authenticity? The Leadership Quarterly, 20(3), 466-482. 
Ghalandari, K., \& Jogh, M. G. G. (2012). The effect of emotional labor strategies (surface acting and deep acting) on job satisfaction and job burnout in Iranian organisations: The role of emotional intelligence. Interdisciplinary Journal of Research in Business, 1(12), 24-31.

George, J. M. (2000). Emotions and leadership: The role of emotional intelligence. Human Relations, 53(8), 1027-1055.

Grandey, A. A. (2000). Emotional regulation in the workplace: A new way to conceptualize emotional labor. Journal of Occupational Health Psychology, 5(1), 95.

Grandey, A. A. (2003). When "the show must go on": Surface acting and deep acting as determinants of emotional exhaustion and peer-rated service delivery. Academy of Management Journal, 46(1), 86-96.

Grandey, A. A., Tam, A. P., \& Brauburger, A. L. (2002). Affective states and traits in the workplace: Diary and survey data from young workers. Motivation and Emotion, 26(1), 31-55.

Hassan, F., \& Omar, S. Z. (2016). Terrorism News Reporting in Southeast Asian Muslim Countries: A Comparative Study of Terrorism Issues as Reported by the Wall Street Journal and the Telegraph (2012-2014). International Journal of Academic Research in Public Policy and Governace, 3(1), 1-16.

Hair, J. F. J., Black, W. C., Babin, B. J., Anderson, R. E., \& Tatham, R. L. (2010). SEM: an introduction. Multivariate Data Analysis: A Global Perspective (7 ${ }^{\text {th }}$ ed., pp. 629-686). Upper Saddle River: Pearson Education.

Hater, J. J., \& Bass, B. M. (1988). Superiors' evaluations and subordinates' perceptions of transformational and transactional leadership. Journal of Applied psychology, 73(4), 695.

Hochschild, A., Irwin, N., \& Ptashne, M. (1983). Repressor structure and the mechanism of positive control. Cell, 32(2), 319-325.

Karatepe, O. M., \& Aleshinloye, K. D. (2009). Emotional dissonance and emotional exhaustion among hotel employees in Nigeria. International Journal of Hospitality Management, 28(3), 349-358.

Levitats, Z., \& Vigoda-Gadot, E. (2017). Yours emotionally: How emotional intelligence infuses public service motivation and affects the job outcomes of public personnel. Public Administration, 95(3), 759-775.

Liang, H. Y., Tang, F. I., Wang, T. F., Lin, K. C., \& Yu, S. (2016). Nurse characteristics, leadership, safety climate, emotional labour and intention to stay for nurses: a structural equation modelling approach. Journal of Advanced Nursing, 72(12), 3068-3080.

Maslach, C., \& Jackson, S. E. (1986). Maslach Burnout Inventory Manual (2 ${ }^{\text {nd }}$ Ed.). Palo Alto: Consulting Psychologist Press.

Maslach, C., Jackson, S. E., \& Leiter, M. P. (1996). Maslach Burnout Inventory Manual (3rd Ed.). Palo Alto: Consulting Psychologists Press.

Mignonac, K., \& Herrbach, O. (2004). Linking work events, affective states, and attitudes: An empirical study of managers' emotions. Journal of Business and Psychology, 19(2), 221-240.

Mumford, M. D., \& Gustafson, S. B. (1988). Creativity syndrome: Integration, application, and innovation. Psychological Bulletin, 103(1), 27.

Naring, G., Briet, M., \& Brouwers, A. (2006). Beyond demand-control: Emotional labour and symptoms of burnout in teachers. Work \& Stress, 20(4), 303-315.

Rowley, J. (2014). Designing and using research questionnaires. Management Research Review, $37(3), 308-330$. 
Spillane, J. P., Hallett, T., \& Diamond, J. B. (2003). Forms of capital and the construction of leadership: Instructional leadership in urban elementary schools. Sociology of Education, 76(1), 1-17.

Saavedra, R., \& Kwun, S. K. (2000). Affective states in job characteristics theory. Journal of Organizational Behavior. The International Journal of Industrial, Occupational and Organizational Psychology and Behavior, 21(2), 131-146.

Schein, S. (2017). A New Psychology for Sustainability Leadership: The Hidden Power of Ecological Worldviews. London: Routledge.

Walsh, M. M., Martin Ginis, K. A., Arnold, K. A., \& Connelly, C. E. (2015). Leadership styles, emotion regulation, and burnout. Journal of Occupational Health Psychology, 20(4), 481.

Wang, C. J. (2019). From emotional labor to customer loyalty in hospitality. International Journal of Contemporary Hospitality Management, 31(9), 3742-3760.

Weiss, H. M., \& Cropanzano, R. (1996). Affective Events Theory: A theoretical discussion of the structure, causes and consequences of affective experiences at work. In B. M. Staw \& L. L. Cummings (Eds.), Research in Organizational Behavior: An Annual Series of Analytical Essays and Critical Reviews, Vol. 18 (p. 1-74), Cambridge: Elsevier Science/JAI Press.

Yilmaz, K., Altinkurt, Y., Guner, M. \& Sen, B. (2015). The Relationship between Teachers' Emotional Labor and Burnout Level. Eurasian Journal of Educational Research, 59, 75-90.

Zapf, D. (2002). Emotion work and psychological well-being: A review of the literature and some conceptual considerations. Human Resource Management Review, 12(2), 237-268.

Zapf, D., \& Holz, M. (2006). On the positive and negative effects of emotion work in organisations. European Journal of Work and Organisational Psychology, 15(1), 1-28. 